\title{
Nitrogen Dynamics Associated with Organic and Inorganic Inputs to Substrate Commonly Used on Rooftop Farms
}

\author{
Angela Y.Y. Kong ${ }^{1}$ \\ Center for Climate Systems Research, Columbia University, 545 West 112th \\ Street, New York, NY 10021
}

Cynthia Rosenzweig

NASA-Goddard Institute for Space Studies, 2880 Broadway, New York, NY 10021

\author{
Joshua Arky \\ Sustainable Development, The Earth Institute, Office of Academic and Research \\ Programs, Columbia University, Hogan, B-Level, New York, NY 10021
}

Additional index words. compost, leachate, organic matter, potential mineralizable nitrogen, rooftop farm, urban agriculture

Abstract. Employing rooftops for the cultivation of crops in limited urban space has garnered interest in densely populated cities in the United States, where there is a growing demand for locally sourced vegetable products. Fertility management recommendations for rooftop farming, however, are scant. With insufficient research on nutrient cycling within rooftop farming systems, which tend to use soilless substrates with low organic matter content, the potential tradeoffs between the negative impacts (e.g., nutrient runoff) and the benefits (e.g., increased locally produced vegetables, stormwater retention, etc.) associated with rooftop farms are unclear. The objective of this study was to evaluate the effects of organic and inorganic nitrogen $(N)$ inputs on the $\mathbf{N}$ dynamics within substrate typically used on rooftop farms. Substrate without added $\mathbf{N}$ inputs (control) was compared with substrates receiving $\mathbf{N}$ sources that are both realistic for and/or reflective of amendments currently applied on urban rooftop farms: a synthetic fertilizer (Osmocote ${ }^{\circledR} 14 \mathrm{~N}-4.2 \mathrm{P}-11.6 \mathrm{~K}$ ), and three organic $\mathrm{N}$ inputscomposted poultry manure, municipal green waste (MGW) compost, and vermicompost. Aboveground crop biomass and yields of Beta vulgaris (swiss chard), along with inorganic $\mathrm{N}$ availability (ammonium: $\mathrm{NH}_{4}^{+}$and nitrate: $\mathrm{NO}_{3}^{-}$), potentially mineralizable nitrogen (PMN), leachate-inorganic $N$ concentrations, and $\mathrm{pH}$ and electrical conductivity (EC) levels were measured during an 8-week greenhouse experiment. Despite differences in carbon-to-nitrogen ratios $(C: N)$, few differences in $N$ cycling and yields were found among the treatments receiving organic $N$ inputs. Crop yields from the synthetic fertilizer and MGW compost treatments were higher than the other organic $\mathbf{N}$ input treatments. Inorganic $\mathbf{N}$ levels in the synthetic fertilizer treatment decreased from $129 \mathrm{mg} \mathrm{N} / \mathrm{L}$ at the start of the season to $113 \mathrm{mg} \mathrm{N} / \mathrm{L}$ at the end of the season, while nearly 10 -fold decreases of inorganic $\mathbf{N}$ concentrations in the substrate of the control and organic $N$ input treatments from week $0(79.5-117.8 \mathrm{mg} \mathrm{N} / \mathrm{L})$ to week 8 (12.8-16.6 $\mathrm{mg}$ N/L) were observed. Greater $N$ availability at critical periods during the season may have promoted greater crop $\mathrm{N}$ uptake efficiency and, therefore, higher yields in the system receiving synthetic fertilizer. However, the greatest losses of $\mathrm{NH}_{4}^{+}$and $\mathrm{NO}_{3}^{-}$via leachate were also measured from this treatment. Our results show that the type of $\mathrm{N}$ input influenced plant-available $N$ and yields and that the MGW compost treatment best achieved the balance between higher yields and reduced $N$ losses to potential roof runoff. Furthermore, additional $N$ inputs to these systems, particularly to the treatments receiving organic composts, will likely be necessary if a high $\mathrm{N}$-demanding crop (such as swiss chard) is to be grown in the same substrates for more than 8 weeks. Rooftop farming is an emergent component of urban agriculture; regulations and guidelines for nutrient management of rooftop farms are necessary to optimize productivity and long-term benefits and to minimize negative environmental impacts.

Expanding agricultural capacity within or close to urban centers has the potential to supplement the growing demand for locally grown produce, while also reducing food transportation costs, lowering greenhouse gas emissions associated with food transportation, increasing food and economic security, and making a positive change in our food systems (Norberg-Hodge et al., 2002). Because land of suitable agricultural quality is often in high demand, and other forms of development are usually more economically viable, land availability is a major obstacle for urban farmers (Whittinghill and Rowe, 2012). Employing rooftops for the cultivation of crops in limited urban space has garnered interest and popularity in densely populated cities in the United States (e.g., Brooklyn Grange Farm in Queens and Brooklyn, NY; Eagle Street Rooftop Farm in Brooklyn, NY; Uncommon Ground, Chicago, IL). Experience with fertility management (e.g., basic $\mathrm{N}$ recommendations) and understanding of the environmental impacts associated with rooftop farms, however, is lacking.

Studies have shown that green roofs can provide multiple environmental benefits to urban areas, including attenuating surface temperatures, mitigating the urban heat island (UHI) effect, managing stormwater retention and flow, and restoring ecological habitat and biodiversity (Brenneisen, 2006; Oberndorfer et al., 2007; Solecki et al., 2005; Teemusk and Mander, 2007; VanWoert et al., 2005). While a rooftop farm essentially applies green roof technology for food production on a building roof, the aforementioned benefits associated with landscaped green roofs may not necessarily be associated with rooftop farms. A key question regarding the environmental impacts of rooftop farms is how does the fertility management of rooftop farms impact stormwater retention, detention, and pollution attenuation? One reason to expect a reduction in environmental benefits is rooftop farms operate with seasonal vegetation, i.e., biomass is low at planting and is then harvested at the end of the season; whereas, landscaped green roofs have perennial biomass cover. It has been suggested that plant establishment and the reduction of labile organic matter in the substrate via decomposition and assimilation would decrease the $\mathrm{NO}_{3}^{-}$leaching from the vegetated green roofs (Berghage et al., 2009). Reduced environmental benefits can also be expected because rooftop farm crops will likely require more nutrient additions (e.g., $\mathrm{N}$ fertilizers) to maintain crop productivity compared with traditional green roof vegetation; this may lead to higher levels of nutrient leaching and unsafe pollutant contamination of stormwater runoff, a major concern for urbanized areas (Gobel et al., 2007; Groffman et al., 2004).

A number of factors (e.g., substrate composition, type of vegetation, and fertilizer additions) can potentially influence the quantity and quality of runoff from vegetated roofs (Czemiel Berndtsson, 2010; Hathaway et al., 2008). Studies evaluating the properties of the substrate material (Moran et al., 2005) and fertilizer application rate (Emilsson et al., 2007) have found that green roof systems can act as sources of $\mathrm{NO}_{3}^{-}$and $\mathrm{NH}_{4}^{+}$. Rooftop farms use soilless substrate, engineered to be lightweight while providing good moisture holding and aeration properties. However, these characteristics also mean that the substrate has limited nutrient holding and retention capacities. After the nutrients in the 
organic component (e.g., compost) of the substrate are depleted, rooftop farms rely on external inputs to maintain their productivity. Nitrogen, a key nutrient, can be introduced through the sole or combined additions of synthetic fertilizers and organic amendments, such as composted animal manure, composted plant and/or food materials, and green manures (e.g., cover crop residues). Unless N availability is well synchronized with plant need and uptake, there is a significant potential for the loss of added $\mathrm{N}$ from vegetated roofs via leaching after irrigation and/or precipitation events. Excess $\mathrm{N}$ from agricultural sources (e.g., fertilizer leaching, runoff from fields, etc.) and urban activities contribute to nutrient pollution in waterways and the degradation of neighboring riparian and marine ecosystems (Carpenter et al., 1998; Michael Beman et al., 2005). In turn, $\mathrm{N}$ leaching from agricultural systems translates to the loss of a principal-often limiting - nutrient in plant growth (Chapin III et al., 1986).

The type and form of $\mathrm{N}$ inputs play a major role in determining the fate and the quantity of $\mathrm{N}$ that will be available for plant uptake as well as $\mathrm{N}$ loss from an agricultural system (e.g., Goh and Haynes, 1986) and from green roofs (e.g., Clark and Zheng, 2013). Compared with synthetic fertilizers, which readily release plant-available $\mathrm{N}$, organic amendments must be mineralized and therefore release mineral $\mathrm{N}$ to field crops slower and more gradually throughout the growing season (e.g., Burger and Jackson, 2003; Sikora and Szmidt, 2001). Mineralization of added organic matter is of particular interest to systems such as rooftop farms that apply organic amendments as the primary source of plant-available N. Composts, particularly those made from food scraps and yard trimmings, will likely be more accessible for urban agriculture as cities and countries recognize the impact of diverting organic waste from landfills on greenhouse gas emissions (Materials Management \& Product Stewardship Workgroup-West Coast Climate and Materials Management Forum, 2011). While the gradual release of inorganic

\footnotetext{
Received for publication 9 Oct. 2014. Accepted for publication 12 Mar. 2015.

Many thanks to Alec Baxt of FarmingUp and Ben Flanner of Brooklyn Grange for their input and for donating the substrate used in this study. Thanks to Krista McGuire (Barnard College) and Kevin Griffin (Lamont-Doherty Earth Observatory, Columbia University) for providing the laboratory space to conduct our experiment and analyses. Thanks also to Ray Sambrotto (Lamont-Doherty Earth Observatory, Columbia University) for the use of his AA3. We also wish to acknowledge Sara Lavenhar, Solaine Master, and John Aurelio for their contributions in the laboratory. Funding for this project was provided by a grant from The Climate Center at Lamont-Doherty Earth Observatory, Columbia University, and the Global Fellows of Sustainable Development Grant at the Earth Institute, Columbia University.

${ }^{1}$ To whom reprint requests should be addressed; e-mailak3132@columbia.edu.
}

$\mathrm{N}$ from composts could also reduce $\mathrm{N}$ losses and substantial evidence indicates that compost applications can improve soil conditions (e.g., Roe, 2001; Smith, 1996), N availability from composts needs to be synchronized with crop demand to optimize crop yield. A better understanding of $\mathrm{N}$ dynamics and cycling in rooftop farm substrate would elucidate how to best manage rooftop farm systems for optimal productivity and environmental benefits, while minimizing $\mathrm{N}$ losses via runoff.

This study is one of the first investigations of $\mathrm{N}$ dynamics in substrate used on rooftop farms. The composts used in this experiment represent feasible $\mathrm{N}$ input options for both conventionally and organically managed urban rooftop farms in New York City, where this study took place. Three hypotheses were tested: 1) synthetic fertilizer will provide the highest $\mathrm{N}$ availability for crop growth, thereby leading to the highest yields, but the high levels of available $\mathrm{N}$ in excess of plant demand will also lead to the greatest loss of $\mathrm{N}$ in leachates compared with the other systems, 2) the organic $\mathrm{N}$ input with the lowest $\mathrm{C}: \mathrm{N}$ ratio will release plant available $\mathrm{N}$ at a rate most closely synchronized with crop $\mathrm{N}$ demand, thereby leading to the smallest $\mathrm{N}$ loss among the systems and the highest yields among the organic $\mathrm{N}$ treatments, and 3) $\mathrm{N}$ release from the organic amendment with the highest $\mathrm{C}: \mathrm{N}$ will not meet plant $\mathrm{N}$ demand and, therefore, lead to reduced yields and the highest leachate- $\mathrm{N}$ among the organic $\mathrm{N}$ treatments.

\section{Materials and Methods}

Experimental design. Starting in June 2012, an 8-week container experiment was conducted in a climate-controlled aluminum and glass rooftop greenhouse at Barnard College, Columbia University (New York, NY). Beta vulgaris (swiss chard) was selected as the test crop because of its high economic value to local rooftop farm businesses (B. Flanner, personal communication). rooflite ${ }^{\circledR}$ intensive ag (Skyland USA LLC, Avondale, PA), a soilless substrate designed for rooftop farms, consisting of lightweight mineral aggregates and an organic composted component [HydRocks ${ }^{\circledR}$ (Big River Industries, Inc., Livingston, AL and Erwinville, LA) and mushroom compost, respectively], was used as the base substrate (select characteristics shown in Table 1). rooflite ${ }^{\circledR}$ intensive ag, alone, served as the control to be evaluated against blends consisting of rooflite ${ }^{\circledR}$ intensive ag amended with four different $\mathrm{N}$ inputs (Table 2): "composted poultry manure" from the Stone Barns Center for Food and Agriculture (Pocantico Hills, NY); MGW compost from the New York City Department of Sanitation, which is available to urban farmers in New York City at no cost; "vermicompost" (compost produced by red wiggler worms, Eisenia foetida) from the Lower East Side Ecology Center (New York, NY), and "synthetic fertilizer" [Osmocote ${ }^{\circledR}$ Smart-Release 14N-4.2P11.6K; The Scotts Company, Marysville,
$\mathrm{OH}$; a resin-coated, granular slow-release fertilizer (The Scott Company, 2009)]. An average of 125,110 , and $170 \mathrm{~g}$ of composted poultry manure, vermicompost, and MGW compost, respectively, were added to an average of $730 \mathrm{~g}$ base substrate per container; these application rates were based on the 1 compost: 4 substrate ratio (by volume) used at the Brooklyn Grange Rooftop Farm (B. Flanner, personal communication). The synthetic fertilizer was added to the substrate according to the manufacturer's recommendation for vegetable plantings $\left[2.5 \mathrm{~g} \cdot \mathrm{L}^{-1}\right.$ substrate (The Scott Company, 2009)]. Estimated rates of $\mathrm{N}$ application on an area basis are reported for each $\mathrm{N}$ addition in Table 2 . The containers for both the control and fertilizer addition treatments contained $\approx 775$ $\mathrm{g}$ substrate, which was equivalent in volume to the treatments receiving the organic $\mathrm{N}$ inputs (e.g., compost plus base substrate; $\approx 11 \mathrm{~cm}$ total substrate depth).

The experiment consisted of the control and four $\mathrm{N}$ input treatments, replicated five times per 2-week destructive sampling interval $[5$ treatments $\times 5$ replicates $\times 5$ sampling events $=125$ total containers (experimental units)]. The containers (round, white, polypropylene pots; $15 \mathrm{~cm}$ diameter; $182 \mathrm{~cm}^{2}$ area; $14 \mathrm{~cm}$ height; $\approx 2 \mathrm{~L}$ volume; ITML-Meyers Industries Inc., Canada) were randomly arranged $\approx 15 \mathrm{~cm}$ apart on greenhouse benches. Two B. vulgaris seeds per container were seeded on 19 June 2012 (week 0 ). Germination was observed on 22 June 2012 and swiss chard plants were subsequently thinned to one shoot per container on 3 July 2012 (week 2). The crop was watered via drip irrigation as needed to prevent wilting and grown to maturity $(\approx 56 \mathrm{~d})$.

\section{Measurements}

Crop and substrate sampling and analyses. Samples of the crop aboveground biomass and substrate were collected biweekly: at the start of the experiment (week 0 ) and weeks 2, 4, 6, and 8. Crop aboveground biomass (referred to as "yield" for the final harvest during week 8) was collected, weighed for fresh weight, dried at $60{ }^{\circ} \mathrm{C}$ until the mass no longer changed, weighed for dry weight, and then ground. From each experimental unit, one subsample of the moist substrate was collected $(\approx 30 \mathrm{~g})$, weighed, passed through a $2-\mathrm{mm}$ sieve, dried at $60{ }^{\circ} \mathrm{C}$, and then ground [in accordance with the standard methodology used for determination of chemical characteristics of green roof substrates (FLL, 2002)]; another subsample of the moist substrate was collected for inorganic $\mathrm{N}$ measurements via the Saturated Media Extract (SME) method (described below). Both aboveground crop biomass and substrate samples were analyzed for $\mathrm{C}$ and $\mathrm{N}$ content using a FLASH EA 1112 elemental analyzer (Thermo Scientific, Cambridge, U.K.).

Plant-available inorganic $\mathrm{N}\left(\mathrm{NH}_{4}^{+}\right.$and $\mathrm{NO}_{3}^{-}$), $\mathrm{pH}$, and $\mathrm{EC}$ values associated with the substrate were measured via the SME method, as described in Warncke (2011). The SME method is currently the established 
method of testing soilless greenhouse media and green roof substrate, both in the United States and internationally. Its goal is to extract the most soluble nutrients that are immediately available to plants. Briefly, deionized water was added to $\approx 60 \mathrm{~g}$ moist substrate to create a saturated paste, and then allowed $90 \mathrm{~min}$ to equilibrate. The $\mathrm{pH}$ of the saturated paste was measured, then the saturated paste was $0.22-\mu \mathrm{m}$-vacuum filtered, and then EC was measured on the extracts before being stored at $-20{ }^{\circ} \mathrm{C}$ until colorimetric analysis. Extracts were thawed before ammonium $\left(\mathrm{NH}_{4}^{+}\right)$and nitrate $\left(\mathrm{NO}_{3}^{-}\right)$analyses using segmented flow analysis (SEAL AutoAnalyzer 3; SEAL, Analytical GmbH, Norderstedt, Germany). Measurements of the substrates taken immediately after amending the rooflite $^{\circledR}$ intensive ag with the four different $\mathrm{N}$ inputs are represented in Table 3 under sampling week 0 .

Leachate collection and analyses. At the onset of the experiment (week 0) and each following week (weeks 1, 2, 3, 4, 5, 6, 7, and 8 ), leachate was collected following the

Table 1. Select specifications (particle size distribution and water measurements) of the rooftop farm substrate (rooflite ${ }^{\circledR}$ intensive ag, Skyland USA, LLC) used in this study. These details were provided by B. Flanner (personal communication).

\begin{tabular}{|c|c|}
\hline $\begin{array}{l}\text { Particle size } \\
\text { analysis (diam; mm) }\end{array}$ & $(\mathrm{Wt} \%)$ \\
\hline$<0.002$ & 2.0 \\
\hline $0.002-0.05$ & 4.6 \\
\hline $0.05-0.25$ & 4.1 \\
\hline $0.25-1.0$ & 10.0 \\
\hline $1.0-2.0$ & 15.7 \\
\hline $2.0-3.2$ & 16.9 \\
\hline $3.2-6.3$ & 36.2 \\
\hline $6.3-9.5$ & 10.4 \\
\hline $9.5-12.5$ & 0.1 \\
\hline$>12.50$ & 0 \\
\hline \multicolumn{2}{|l|}{ Physical measurements } \\
\hline Bulk density (dry, $\mathrm{g} \cdot \mathrm{cm}^{-3}$ ) & 0.65 \\
\hline Bulk density (at max. water & \\
\hline holding capacity, $\mathrm{g} \cdot \mathrm{cm}^{-3}$ ) & 1.08 \\
\hline Total pore volume (\%) & 63.7 \\
\hline $\begin{array}{l}\text { Maximum water holding } \\
\text { capacity }(\%)\end{array}$ & 44.7 \\
\hline $\begin{array}{l}\text { Air-filled porosity (at max } \\
\quad \text { water holding capacity, \%) }\end{array}$ & 19.0 \\
\hline $\begin{array}{l}\text { Saturated hydraulic } \\
\text { conductivity }\left(\mathrm{cm} \cdot \mathrm{s}^{-1}\right)\end{array}$ & 0.058 \\
\hline
\end{tabular}

Table 2. Total nitrogen $(\mathrm{N})$ content and carbon-to-nitrogen $(\mathrm{C}: \mathrm{N})$ ratio of the organic $\mathrm{N}$ input additions and the substrate (control), along with the amount of $\mathrm{N}$ applied via the $\mathrm{N}$ additions to the different treatments. Mean separation in the same column, among organic N inputs only, by Tukey's honestly significant difference test at $\alpha=0.05$.

\begin{tabular}{|c|c|c|c|c|}
\hline Treatment & $\mathrm{N}$ input & $\begin{array}{l}\text { Total N } \\
(\mathrm{g} \mathrm{N} / \mathrm{kg})\end{array}$ & $\mathrm{C}: \mathrm{N}$ & $\begin{array}{c}\mathrm{N} \text { application } \\
(\mathrm{kg} \mathrm{N} / \mathrm{ha})\end{array}$ \\
\hline Municipal green waste & Composted municipal green waste & $11.0 \mathrm{~b}$ & $22.9 \mathrm{a}$ & 189 \\
\hline Composted poultry manure & Composted poultry manure & $10.7 \mathrm{~b}$ & $23.0 \mathrm{a}$ & 136 \\
\hline Vermicompost & Vermicompost & $12.3 \mathrm{a}$ & $13.0 \mathrm{~b}$ & 170 \\
\hline \multirow[t]{2}{*}{ Synthetic fertilizer } & Osmocote ${ }^{\circledR}$ Smart-Release & & & \\
\hline & $14-14-14^{y}$ & 140 & NA & 126 \\
\hline Control & & $6.57^{x}$ & 19.5 & 0 \\
\hline
\end{tabular}

zTo $30 \mathrm{~cm}$ depth.

${ }^{\mathrm{y}} 14 \mathrm{~N}-4.2 \mathrm{P}-11.6 \mathrm{~K}$.

${ }^{\mathrm{x}}$ Total $\mathrm{N}$ content of rooflite ${ }^{\circledR}$ intensive ag substrate at week 0 .

PourThru program, adapted from Whipker et al., (2001). Before collecting leachate, all containers were irrigated to saturation. After draining for $1 \mathrm{~h}$, deionized water was added to designated containers (e.g., during weeks 1 and 2, leachate was collected from pots assigned for destructive sampling in week 2 ) to collect $\approx 70 \mathrm{~mL}$ leachate from each container $(\approx 50 \%$ of total volume of deionized water applied). The leachate was subsequently filtered through Whatman no. 1 filter paper and $\mathrm{EC}$ and $\mathrm{pH}$ were measured. About $30 \mathrm{~mL}$ of the leachate was subsampled, $0.22-\mu \mathrm{m}$-filtered, and then stored at $-20{ }^{\circ} \mathrm{C}$ until colorimetric analysis for inorganic $\mathrm{N}$ content (in the same manner as that described above for the SME extracts).

PMN measurements. Potentially mineralizable $\mathrm{N}$ estimates have been widely used to assess the effects of various management practices, such as tillage, crop rotations, and fertilization, on $\mathrm{N}$ availability (e.g., Campbell and Souster, 1982; Doran, 1987; Franzluebbers et al., 1995). Potentially mineralizable $\mathrm{N}$ was measured using a 28 -day aerobic incubation study, following the method outlined in Curtin and Campbell for mineral soils (Curtin and Campbell, 2006), which was similar to the method used to measure PMN in a soilless potting mix (Boydston et al., 2008). About 48 h before the start of the incubation, $10 \mathrm{~g}$ of 4-mmsieved moist substrate from each of the treatments (five replicates per treatment) was brought to $20 \%$ water holding capacity (WHC) with deionized water. This equilibration or "priming" step is necessary to avoid the period of stimulated microbial activity upon rewetting the substrate. After priming, samples were brought to $60 \%$ WHC and sealed within canning jars $(946 \mathrm{~mL})$. On day 0 of the incubation, $3 \mathrm{~h}$ after being placed in the canning jars, one set of samples was extracted with $100 \mathrm{~mL} 0.0125 \mathrm{M} \mathrm{CaCl}_{2}$ at a rate of 1 sample: 10 extractant $(\mathrm{w} / \mathrm{v})$ [according to the guidelines for soil analyses of green roof substrates (FLL, 2002)] and then shaken on a reciprocating shaker at $\approx 150 \mathrm{rpm}$ for $1 \mathrm{~h}$. The slurries were filtered through a Whatman no. 1 filter, and $\mathrm{EC}$ and $\mathrm{pH}$ were measured on the extracts. Extracts were $0.22-\mu \mathrm{m}$-syringe filtered and stored at $-20{ }^{\circ} \mathrm{C}$. The second set of samples was incubated at $\approx 25{ }^{\circ} \mathrm{C}$ for $28 \mathrm{~d}$, and aerated every three days for $\approx 10 \mathrm{~min}$. On the final day of the incubation (day 28), the samples were removed from the jars and extracted in the same manner as the first set of samples. Frozen extracts were thawed and then analyzed for $\mathrm{NH}_{4}^{+}$and $\mathrm{NO}_{3}^{-}$as per the methods described above for the SME method. Potentially mineralizable $\mathrm{N}$ was calculated as the difference between day 28 and day 0 concentrations of $\mathrm{N}$ derived from both $\mathrm{NH}_{4}^{+}$and $\mathrm{NO}_{3}^{-}$. In principle, this extraction with $\mathrm{CaCl}_{2}$ will remove more nutrients from the substrate than the SME method since the salt solutions were developed to extract quantities of nutrients that could be available in field soils over a growing season.

\section{Statistical analyses}

Analysis of variance (ANOVA) was used to compare the sensitivity of substrate $\mathrm{C}$ and $\mathrm{N}$ content, yields and crop- $\mathrm{N}$, inorganic $\mathrm{N}$ in leachate, $\mathrm{pH}$ and $\mathrm{EC}$ values, and $\mathrm{PMN}$ concentrations with regard to experimental factors (sampling week and $\mathrm{N}$ input) using the function aov() of the R software package ( $R, 2013$ ). Means separation was found using Tukey's honestly significant difference, and significance was determined at $\alpha=0.05$ unless otherwise stated. Because treatments destructively sampled at different sampling periods were represented by distinct experimental units, ANOVA was also used to compare treatment means across sampling periods, rather than apply a multivariate ANOVA repeated analysis. Homogeneity of variances could not be achieved via transformation for: $\mathrm{NH}_{4}^{+}-\mathrm{N}$ in extracts from weeks 2 and $6 ; \mathrm{NH}_{4}^{+}-\mathrm{N}$ in leachates from weeks 1,2 , 4 , and $6 ; \mathrm{NO}_{3}^{-}-\mathrm{N}$ in extracts from week $8 ; \mathrm{EC}$ in extracts from week 6 , and leachates from weeks 0 and 3; $\mathrm{pH}$ in leachates from weeks 2 and $6 ; \mathrm{NH}_{4}^{+}-\mathrm{N}$ and $\mathrm{NO}_{3}^{-}-\mathrm{N}$ in leachate from weeks 5,7 , and 8 (Table 3 ). In these instances, results were interpreted with caution and greater scrutiny.

\section{Results and Discussion}

\section{Nitrogen dynamics}

Plant-available nitrogen. With the exception of week 0 , substrate $\mathrm{NO}_{3}^{-}-\mathrm{N}$ concentrations were consistently higher (by at least $30 \%$ ) in the synthetic fertilizer treatment than the treatments receiving organic $\mathrm{N}$ inputs (Table 3). The higher availability of $\mathrm{NO}_{3}^{-}-\mathrm{N}$ in the synthetic fertilizer treatment was likely due to the formulation of this $\mathrm{N}$ input, i.e., readily available ammonium nitrate and ammonium phosphate. Despite week-to-week variability within the treatments (e.g., substrate $\mathrm{NO}_{3}^{-} \mathrm{N}$ concentrations in the vermicompost treatment increased from week 0 to 2 and then decreased in the subsequent weeks), plant available $\mathrm{NO}_{3}^{-}-\mathrm{N}$ in the control and all four $\mathrm{N}$ input treatments decreased linearly over the course of the experiment (rates not shown). The $\mathrm{NO}_{3}^{-}-\mathrm{N}$ concentrations in the substrate of the control and organic $\mathrm{N}$ input treatments showed nearly a 10 -fold decrease from week 0 to week 8 (Table 3 ); in contrast, $\mathrm{NO}_{3}^{-}-\mathrm{N}$ concentrations in the substrate of synthetic fertilizer treatment 
Table 3. Measurements of $\mathrm{pH}$, electrical conductivity (EC), total nitrogen $(\mathrm{N})$, carbon-to-nitrogen ratio $(\mathrm{C}: \mathrm{N})$, and inorganic $\mathrm{N}$ levels $\left(\mathrm{NO} 3^{-}-\mathrm{N}\right.$ and $\left.\mathrm{NH}_{4}^{+}-\mathrm{N}\right)$ in the substrate at sampling events during an 8-week greenhouse experiment. Means $(\mathrm{n}=5)$ among treatments within a sampling week not followed by the same letter are significantly different at $P \leq 0.05$.

\begin{tabular}{|c|c|c|c|c|c|c|c|}
\hline Sampling week & $\mathrm{N}$ input treatment ${ }^{\mathrm{z}}$ & $\mathrm{pH}$ & $\mathrm{EC}\left(\mathrm{dS} \cdot \mathrm{m}^{-1}\right)$ & Substrate N (g N/kg) & $\mathrm{C}: \mathrm{N}$ & $\mathrm{NO}_{3}^{-}-\mathrm{N}\left(\mathrm{mg} \cdot \mathrm{L}^{-1}\right)$ & $\mathrm{NH}_{4}^{+}-\mathrm{N}\left(\mathrm{mg} \cdot \mathrm{L}^{-1}\right)$ \\
\hline \multirow[t]{5}{*}{$\overline{0}$} & Control & $7.39 \mathrm{a}$ & $5.61 \mathrm{a}$ & $6.57 \mathrm{a}$ & $19.8 \mathrm{a}$ & $117.8 \mathrm{a}$ & $1.22 \mathrm{~b}$ \\
\hline & MGW compost & $7.48 \mathrm{a}$ & $7.66 \mathrm{a}$ & $7.06 \mathrm{a}$ & $17.9 \mathrm{~b}$ & $99.3 \mathrm{a}$ & $0.30 \mathrm{~b}$ \\
\hline & Synthetic fertilizer & $7.22 \mathrm{~b}$ & $6.99 \mathrm{a}$ & $5.99 \mathrm{a}$ & $19.1 \mathrm{ab}$ & $113.9 \mathrm{a}$ & $15.2 \mathrm{a}$ \\
\hline & Composted poultry manure & $7.39 \mathrm{a}$ & $5.30 \mathrm{a}$ & $8.03 \mathrm{a}$ & $17.2 \mathrm{bc}$ & $94.5 \mathrm{a}$ & $0.88 \mathrm{~b}$ \\
\hline & Vermicompost & $7.51 \mathrm{a}$ & $4.32 \mathrm{a}$ & $8.52 \mathrm{a}$ & $16.0 \mathrm{~b}$ & $79.5 \mathrm{a}$ & $0.97 \mathrm{~b}$ \\
\hline \multirow[t]{5}{*}{2} & Control & $7.51 \mathrm{a}$ & $4.38 \mathrm{~b}$ & $8.07 \mathrm{ab}$ & $19.6 \mathrm{a}$ & $70.2 \mathrm{c}$ & $0.24 \mathrm{~b}$ \\
\hline & MGW compost & $7.43 \mathrm{ab}$ & $4.66 \mathrm{~b}$ & $9.05 \mathrm{a}$ & $17.4 \mathrm{ab}$ & $61.4 \mathrm{c}$ & $0.39 \mathrm{~b}$ \\
\hline & Synthetic fertilizer & $6.97 \mathrm{c}$ & $7.11 \mathrm{a}$ & $6.63 \mathrm{~b}$ & $19.1 \mathrm{a}$ & $165.8 \mathrm{a}$ & $30.8 \mathrm{a}$ \\
\hline & Composted poultry manure & $7.38 \mathrm{~b}$ & $4.28 \mathrm{~b}$ & $9.52 \mathrm{a}$ & $17.0 \mathrm{~b}$ & $88.8 \mathrm{bc}$ & $0.53 \mathrm{~b}$ \\
\hline & Vermicompost & $7.51 \mathrm{a}$ & $4.58 \mathrm{~b}$ & $9.63 \mathrm{a}$ & $16.0 \mathrm{~b}$ & $116.3 \mathrm{~b}$ & $0.39 \mathrm{~b}$ \\
\hline \multirow[t]{5}{*}{4} & Control & $7.65 \mathrm{a}$ & $3.14 \mathrm{a}$ & $8.82 \mathrm{~b}$ & $18.4 \mathrm{a}$ & $50.0 \mathrm{~b}$ & $0.50 \mathrm{~b}$ \\
\hline & MGW compost & $7.70 \mathrm{a}$ & $4.83 \mathrm{a}$ & $8.88 \mathrm{~b}$ & $16.5 \mathrm{~b}$ & $48.1 \mathrm{~b}$ & $1.03 \mathrm{~b}$ \\
\hline & Synthetic fertilizer & $7.39 \mathrm{~b}$ & $4.78 \mathrm{a}$ & $8.69 \mathrm{~b}$ & $16.9 \mathrm{ab}$ & $131.8 \mathrm{a}$ & $28.7 \mathrm{a}$ \\
\hline & Composted poultry manure & $7.61 \mathrm{a}$ & $3.30 \mathrm{a}$ & $11.6 \mathrm{a}$ & $16.2 \mathrm{bc}$ & $61.3 \mathrm{~b}$ & $0.34 \mathrm{~b}$ \\
\hline & Vermicompost & $7.72 \mathrm{a}$ & $3.31 \mathrm{a}$ & $9.51 \mathrm{ab}$ & $14.7 \mathrm{c}$ & $64.7 \mathrm{~b}$ & $1.02 \mathrm{~b}$ \\
\hline \multirow[t]{5}{*}{6} & Control & $7.55 \mathrm{~b}$ & $4.26 \mathrm{ab}$ & $8.32 \mathrm{a}$ & $18.8 \mathrm{a}$ & $60.0 \mathrm{a}$ & $1.28 \mathrm{~b}$ \\
\hline & MGW compost & $7.77 \mathrm{a}$ & $5.26 \mathrm{a}$ & $9.56 \mathrm{a}$ & $16.2 \mathrm{~b}$ & $26.9 \mathrm{~b}$ & $0.67 \mathrm{~b}$ \\
\hline & Synthetic fertilizer & $7.45 \mathrm{bc}$ & $4.67 \mathrm{ab}$ & $8.85 \mathrm{a}$ & $16.9 \mathrm{ab}$ & $68.3 \mathrm{a}$ & $28.8 \mathrm{a}$ \\
\hline & Composted poultry manure & $7.68 \mathrm{ab}$ & $2.75 \mathrm{ab}$ & $9.94 \mathrm{a}$ & $17.4 \mathrm{ab}$ & $39.4 \mathrm{ab}$ & $0.61 \mathrm{~b}$ \\
\hline & Vermicompost & $7.71 \mathrm{a}$ & $2.45 \mathrm{~b}$ & $9.55 \mathrm{a}$ & $15.4 \mathrm{bc}$ & $33.5 \mathrm{~b}$ & $0.61 \mathrm{~b}$ \\
\hline \multirow[t]{5}{*}{8} & Control & $7.46 \mathrm{a}$ & $2.53 \mathrm{a}$ & $7.30 \mathrm{~b}$ & $19.0 \mathrm{a}$ & $16.6 \mathrm{~b}$ & $0.49 \mathrm{~b}$ \\
\hline & MGW compost & $7.38 \mathrm{a}$ & $3.33 \mathrm{a}$ & $9.50 \mathrm{ab}$ & $17.1 \mathrm{ab}$ & $13.7 \mathrm{~b}$ & $0.64 \mathrm{~b}$ \\
\hline & Synthetic fertilizer & $7.00 \mathrm{~b}$ & $4.41 \mathrm{a}$ & $7.50 \mathrm{~b}$ & $19.1 \mathrm{a}$ & $84.0 \mathrm{a}$ & $29.0 \mathrm{a}$ \\
\hline & Composted poultry manure & $7.39 \mathrm{a}$ & $2.73 \mathrm{a}$ & $10.4 \mathrm{a}$ & $16.8 \mathrm{~b}$ & $14.9 \mathrm{~b}$ & $0.84 \mathrm{~b}$ \\
\hline & Vermicompost & $7.39 \mathrm{a}$ & $2.46 \mathrm{a}$ & $10.0 \mathrm{a}$ & $15.4 \mathrm{bc}$ & $12.8 \mathrm{~b}$ & $0.67 \mathrm{~b}$ \\
\hline
\end{tabular}

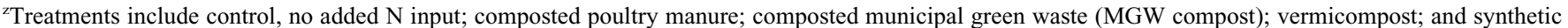
fertilizer, Osmocote ${ }^{\circledR}$ Smart-Release $14 \mathrm{~N}-4.2 \mathrm{P}-11.6 \mathrm{~K}$.

were $\approx 114 \mathrm{mg} \cdot \mathrm{L}^{-1}$ at week 0 , increased to $\approx 166 \mathrm{mg} \cdot \mathrm{L}^{-1}$ at week 2 , and did not fall below $68 \mathrm{mg} \cdot \mathrm{L}^{-1}$ for the remainder of the experiment (Table 3). The concentration of plant-available $\mathrm{NH}_{4}^{+}-\mathrm{N}$ in the synthetic fertilizer treatment after week 0 was consistently $\approx 30 \mathrm{mg} \cdot \mathrm{L}^{-1}$. This was an order of magnitude higher than $\mathrm{NH}_{4}^{+}-\mathrm{N}$ concentrations in the treatments amended with compost $\left(<1 \mathrm{mg} \cdot \mathrm{L}^{-1}\right.$, Table 3$)$. Plant available $\mathrm{NH}_{4}^{+}-\mathrm{N}$ in neither the control nor the $\mathrm{N}$ input treatments showed significant changes across the season, though. The pool of plant-available $\mathrm{NO}_{3}^{-}-\mathrm{N}$ in the synthetic fertilizer treatment was only $\approx 10 \times$ larger than that of $\mathrm{NH}_{4}^{+}-\mathrm{N}$ across the season, whereas, substantially more $\mathrm{N}$ was available as $\mathrm{NO}_{3}^{-}$than as $\mathrm{NH}_{4}^{+}$ in the control and organic $\mathrm{N}$ input treatments $(\approx 10-100$ times more). By the end of the season, the proportion of $\mathrm{N}$ available as $\mathrm{NO}_{3}^{-}$ vs. $\mathrm{NH}_{4}^{+}$declined more in the control and organic $\mathrm{N}$ input treatments than in the substrate receiving synthetic fertilizer (data not shown). The greater decrease in the ratio of $\mathrm{NO}_{3}^{-}-\mathrm{N}: \mathrm{NH}_{4}^{+}-\mathrm{N}$ suggests that $\mathrm{N}$ mineralization and subsequent release of $\mathrm{NO}_{3}^{-}-\mathrm{N}$ and $\mathrm{NH}_{4}^{+}-\mathrm{N}$ from the compost treatments and the control were less consistent than mineral $\mathrm{N}$ release in the synthetic fertilizer treatment (at the rates applied).

Substrate depths on rooftop farms are similar to intensive green roof depths $(>17 \mathrm{~cm})$. To the best of the authors' knowledge, nutrient application recommendations are, however, not easily obtainable for intensive green roofs planted with vegetable crops. The common practice regarding intensive green roof fertilization is one that is endorsed by green roof expert, Charlie Miller, P.E., and that is to apply care and maintenance as prescribed to a similar garden situation (Roofmeadow, 2015). The total $\mathrm{N}$ application via the synthetic fertilizer treatment was similar to an $\mathrm{N}$ fertilization recommendation of $136 \mathrm{~N} \mathrm{~kg} \cdot \mathrm{ha}^{-1}$ for field-grown swiss chard (Masabni, 2011); whereas, the total $\mathrm{N}$ applied from the composted poultry manure, MGW compost, and vermicompost were 13,58 , and $42 \%$ higher than the recomemendation for field-grown swiss chard. Despite the lower N application rate, the synthetic fertilizer treatment provided a more consistent supply of both $\mathrm{NO}_{3}^{-}$- and $\mathrm{NH}_{4}^{+}-\mathrm{N}$ throughout the period of the study, which might have been better synchronized with swiss chard $\mathrm{N}$ need and uptake than the organic $\mathrm{N}$ input treatments with higher $\mathrm{N}$ application rates.

Potentially mineralizable nitrogen. Although the $\mathrm{C}: \mathrm{N}$ ratios of the composts were expected to be strong predictors of the size of the PMN pools [i.e., the lower the C:N, the larger the PMN pool (Nicolardot et al., 2001)] and there were differences in $C: N$ among the $\mathrm{N}$ input treatments at week 0 ( Table 3), no significant differences in total PMN were found among treatments (Fig. 1). This suggests that the contribution of mineralization to plant-available $\mathrm{N}$ is not different among the treatments. While the lack of differences in PMN among the $\mathrm{N}$ input treatments corresponds with the similarities in substrate and inorganic $\mathrm{N}$ availability $\left(\mathrm{NO}_{3}^{-}\right.$and $\left.\mathrm{NH}_{4}^{+}\right)$at week 0 , it does not reflect the differences in inorganic and total $\mathrm{N}$ in the

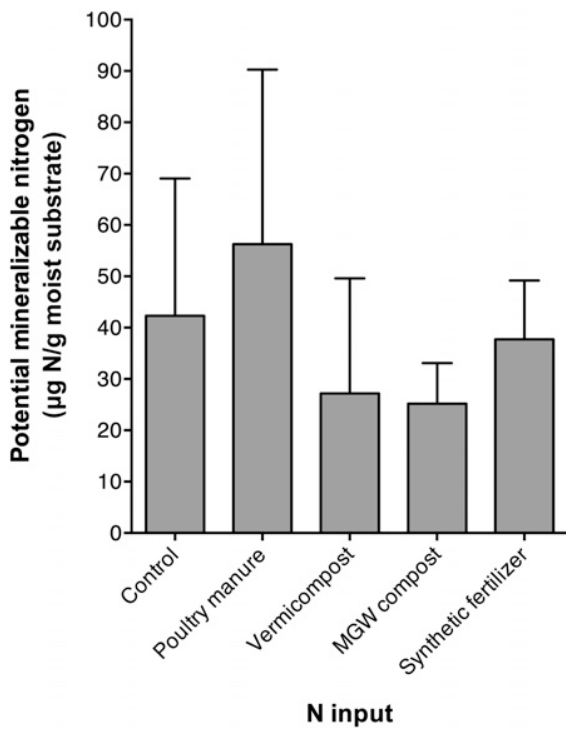

Fig. 1. Potential nitrogen mineralization $(\mu \mathrm{g} \mathrm{N} / \mathrm{g}$ moist substrate) measured by 28 -day aerobic laboratory incubation. Treatments include control, no added $\mathrm{N}$ input to rooftop farm substrate; poultry manure, composted poultry manure; vermicompost; municipal green waste (MGW) compost, composted municipal green waste; and synthetic fertilizer, Osmocote ${ }^{\circledR}$ Smart-Release $14 \mathrm{~N}-4.2 \mathrm{P}-11.6 \mathrm{~K}$. Error bars represent standard error of the mean $(n=5)$.

substrates at the end of the experiment (Table 3 ). Also, the higher total substrate $\mathrm{N}$ content of the compost amended systems at the end of the experiment suggested that these systems had a larger pool of total $\mathrm{N}$ that could be 
potentially mineralized beyond the duration of the experiment in comparison with the control and synthetic fertilizer treatment.

Assuming that $\mathrm{N}$ mineralization under optimum temperature and moisture in the substrate follows first-order kinetics (Stanford and Smith, 1972), potential N mineralization rates in the control, composted poultry manure, and vermicompost treatments were calculated to be $0.04 \mathrm{mg} \mathrm{N} / \mathrm{L} / \mathrm{d}$, while the MGW compost and fertilizer treatments had PMN rates of 0.05 and $0.06 \mathrm{mg} \mathrm{N} / \mathrm{L} / \mathrm{d}$, respectively. No significant differences for PMN rates among the treatments were found (data not shown). In systems with slower $\mathrm{N}$ mineralization rates, we expect the total mineralized $\mathrm{N}$ to be made available to the crop later but potentially over a longer period than systems with faster PMN rates. Moreover, lower $\mathrm{N}$ mineralization rates could correspond to a reduced risk for $\mathrm{N}$ leaching.

As an $\mathrm{N}$ availability index, PMN, as measured here with a 28-d aerobic incubation, does not correlate with inorganic $\mathrm{N}$ measurements or yields (data shown below). Given the importance of estimating $\mathrm{N}$ availability for fertility recommendations for rooftop farm substrate, it would be in the interest of urban growers to identify techniques for predicting $\mathrm{N}$ availability and its relationships to total substrate N, yields, etc. (Schomberg et al., 2009).

Inorganic $\mathrm{N}$ in leachate. Rooftop farmers face the challenge of applying $\mathrm{N}$ in sufficient amounts to maintain crop yields, while not contributing to nutrient loading of stormwater runoff, which would diminish the benefits associated with a vegetated roof. Concentrations of $\mathrm{NO}_{3}^{-} \mathrm{N}$ in the leachate from the synthetic fertilizer and organic $\mathrm{N}$ input treatments at week 0 ranged from 49.5 to $129.9 \mathrm{mg}$ $\mathrm{NO}_{3}^{-}-\mathrm{N} / \mathrm{L}$ (Fig. 2) and decreased to a range between 2.99 and $23.9 \mathrm{mg} \mathrm{NO}_{3}^{-}-\mathrm{N} / \mathrm{L}$ by week 8 . At weeks $0,1,4,5$, and 8 , leachate from the synthetic fertilizer addition had a significantly higher concentration of $\mathrm{NO}_{3}^{-}-\mathrm{N}$ than leachate from the organic $\mathrm{N}$ input treatments and the control (Fig. 2). The relatively higher concentration of $\mathrm{NO}_{3}^{-}-\mathrm{N}$ in the leachate from the synthetic fertilizer treatment suggests greater negative implications from the proliferation of this type of $\mathrm{N}$ input than the compost amendments to rooftop farms. Reduced rates of mineralization of the composts and immmobilization of existing $\mathrm{NO}_{3}^{-}-\mathrm{N}$ in the substrate as a result of the increase in $\mathrm{C}$ from the composts may have contributed to lower $\mathrm{NO}_{3}^{-}-\mathrm{N}$ concentrations in the leachate of the organic $\mathrm{N}$ input treatments.

Ammonium- $\mathrm{N}$ in the leachate was highest in the synthetic fertilizer treatment at all sampling weeks (Fig. 3). Concentrations of $\mathrm{NH}_{4}^{+}-\mathrm{N}$ in the leachate of the control and treatments receiving organic $\mathrm{N}$ inputs did not significantly change over the crop growth period $\left(0.2-0.45 \mathrm{mg} \mathrm{NH}{ }_{4}^{+}-\mathrm{N} / \mathrm{L}\right)$ and no differences in $\mathrm{NH}_{4}^{+}-\mathrm{N}$ were found among the leachate of the organic $\mathrm{N}$ input treatments. The overall low levels of $\mathrm{NH}_{4}^{+}-\mathrm{N}$ in both the leachate and in the substrate may have been

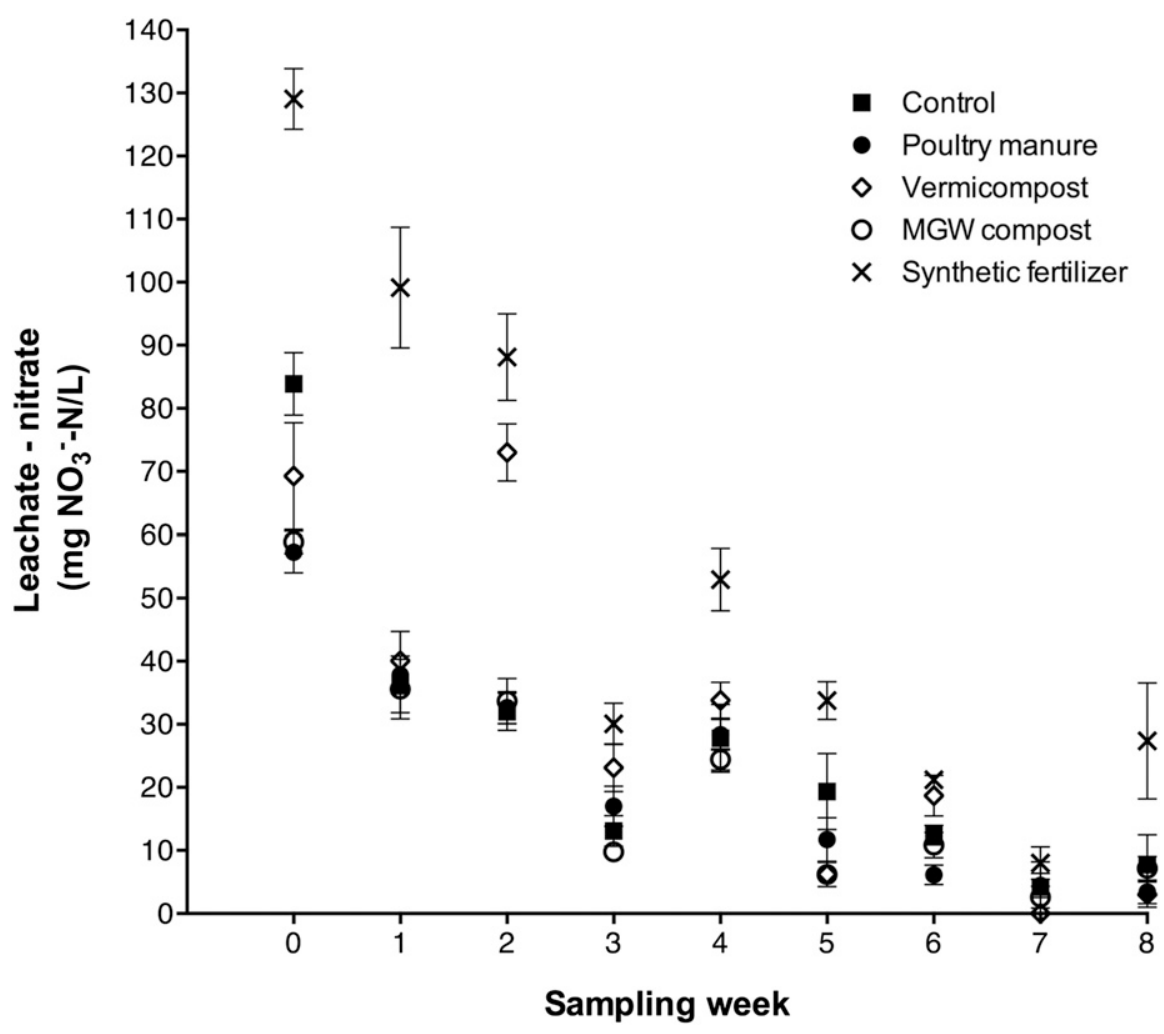

Fig. 2. Total nitrate concentration $\left(\mathrm{mg} \mathrm{NO}_{3}^{-}-\mathrm{N} / \mathrm{L}\right)$ in leachate water from rooftop farm substrate during an 8-week greenhouse experiment. Treatments include control, no added $\mathrm{N}$ input to rooftop farm substrate; poultry manure, composted poultry manure; vermicompost; municipal green waste (MGW) compost, composted municipal green waste; and synthetic fertilizer, Osmocote ${ }^{\circledR}$ Smart-Release 14N4.2P-11.6K. Error bars represent standard error of the mean $(n=5)$.

the result of substrate conditions, such as sufficient aeration and $\mathrm{pH}$ in the range of 6 to 8 , that are favorable to the process of nitrification (conversion of $\mathrm{NH}_{4}^{+}$to $\mathrm{NO}_{3}^{-}$) (Norton, 1999).

The Environmental Protection Agency (Repository of Documents: New York State, 2000) has established enforceable standards for $\mathrm{NO}_{3}^{-}$- and $\mathrm{NH}_{4}^{+}-\mathrm{N}$ concentrations in surface water at 10 and $2 \mathrm{ppm}\left(\mathrm{ppm} \sim \mathrm{mg} \cdot \mathrm{L}^{-1}\right)$, respectively. For six weeks of the experiment, $\mathrm{NO}_{3}^{-}-\mathrm{N}$ levels in the leachate of all treatments exceeded the EPA surface water quality guidelines. In weeks $0,4,6$, and 8 , $\mathrm{NH}_{4}^{+}-\mathrm{N}$ in the leachate from the synthetic fertilizer treatment exceeded the EPA surface water quality guidelines, whereas $\mathrm{NH}_{4}^{+}-\mathrm{N}$ in the leachate from compost treatments and the control remained within the EPA standards throughout the experiment. The significantly higher concentrations of inorganic $\mathrm{N}$ in the leachate from the substrate receiving synthetic fertilizer would require either more treatment (possibly via enhancement of denitrification processes during retention within the layers of the green roof system) or greater dilution than the leachate from substrates amended with composts to meet EPA water quality standards. However, green roof runoff is not governed by EPA water quality regulations and runoff from a rooftop farm would likely undergo dilution with other water sources before discharge to EPA compliance points. Our leachate data, though not collected in situ from a rooftop farm experiment, suggest that the potential negative impact of the inorganic $\mathrm{N}$ in runoff from rooftop farm substrates on stormwater quality might need greater monitoring and attenuation compared with runoff from other types of green roofs that do not require the higher annual $\mathrm{N}$ inputs that a rooftop farm operation receives to maintain productivity.

Several factors (similar to those for landscaped green roofs) potentially influence runoff dynamics from rooftop farms: substrate composition, thickness, and drainage; maintenance and amendments used; type of vegetation; precipitation volume and patterns; local pollution sources and properties; and age of the growth substrate. The porous nature of the rooflite ${ }^{\circledR}$ intensive ag substrate might create a well-oxygenated environment that could encourage nitrification, which could potentially deplete $\mathrm{NH}_{4}^{+}-\mathrm{N}$ that was not taken up by the crop. On a working rooftop farm where the volume of moisture passing through the substrate varies with precipitation events and irrigation, the mineralization of organic amendments as well as the release of $\mathrm{N}$ from synthetic fertilizers might show different patterns and rates compared with those from this experiment, in which moisture and temperature conditions were controlled. Also, it can be expected that over time and growing seasons, substrate particles may dissolve and be removed along with leachates, the chemical composition of 
the substrate will change, and the porosity of the substrate may be altered by crop roots and compaction. On-farm research is needed to better understand the impacts of rooftop farm fertility management on stormwater runoff quality.

Yields and crop N. Swiss chard biomass (fresh weight of aboveground biomass) was similar among the treatments at week 2 (Fig. 4). In weeks 4 and 6 , the synthetic fertilizer treatment showed a significant increase in swiss chard biomass compared with the MGW compost treatment and the control. At harvest (week 8), the yield in the treatment receiving synthetic fertilizer (fresh weight $=$ $44.4 \mathrm{~g}$ ) was nearly $67 \%$ higher than the yield from the control (Fig. 4). Although biomass in the MGW compost treatment was lower than the synthetic fertilizer at weeks 4 and 6, yields between these two treatments were similar at harvest. Throughout the experiment, biomass and yields among the compost treatments were not different and did not differ from the control (Fig. 4).

In a greenhouse study, Echer et al. (2012) evaluated the impact of a range of urea-N fertilization doses on swiss chard and found linear increases in total and marketable yields (5.4 t.ha ${ }^{-1}$ increase for each $40 \mathrm{~kg} \cdot \mathrm{ha}^{-1} \mathrm{~N}$ applied). Engelbrecht et al. (2010) found the fresh biomass weight of swiss chard increased with increasing $\mathrm{N}$ doses and did not show a decrease even at an application of $800 \mathrm{~kg}$ $\mathrm{N} /$ ha. The $\mathrm{N}$ application rates in our study (126-189 kg N/ha) approached the highest N dose in the Echer et al. (2012) study (160 kg $\mathrm{N} / \mathrm{ha}$ ), but were less than $25 \%$ of the highest $\mathrm{N}$ dose used in Engelbrecht et al. (2010). Therefore, applying more $\mathrm{N}$ to the rooftop farm substrate might still lead to a linear increase in swiss chard yields. However, other factors, such as phosphorus concentration, planting density, salinity, etc., could become limiting to growth at higher $\mathrm{N}$ input levels.

At harvest, $\mathrm{N}$ content of the swiss chard yields among the four treatments were not different from the control (Table 4). Despite the generally higher inorganic $\mathrm{N}$ availability in the the synthetic fertilizer treatment, yield $\mathrm{N}$ (33 g N/kg biomass) in the synthetic fertilizer treatment was similar to the yield $\mathrm{N}$ from the organic $\mathrm{N}$ input treatments and was only higher than $\mathrm{N}$ content in swiss chard from the composted poultry manure treatment (21 g N/kg biomass). The higher C:N ratio in the swiss chard from the composted poultry manure $(\mathrm{C}: \mathrm{N}=15.2)$ vs. the synthetic fertilizer addition treatment $(\mathrm{C}: \mathrm{N}=10.9 ; P=$ 0.06 ; Table 4) was consistent with the differences observed in yield $\mathrm{N}$.

\section{Fertility management}

Substrate conditions: $p H$ and EC. Along with organic matter content, green roof substrate characteristics that are important to nutrient release include salinity, $\mathrm{pH}$, particle size, porosity, and WHC (FLL, 2002). We observed $\mathrm{pH}$ values within the range of 6.97 to 7.77 for all treatments across the season (Table 3). Values of $\mathrm{pH}$ were generally highest at weeks 4 and 6 and did not change

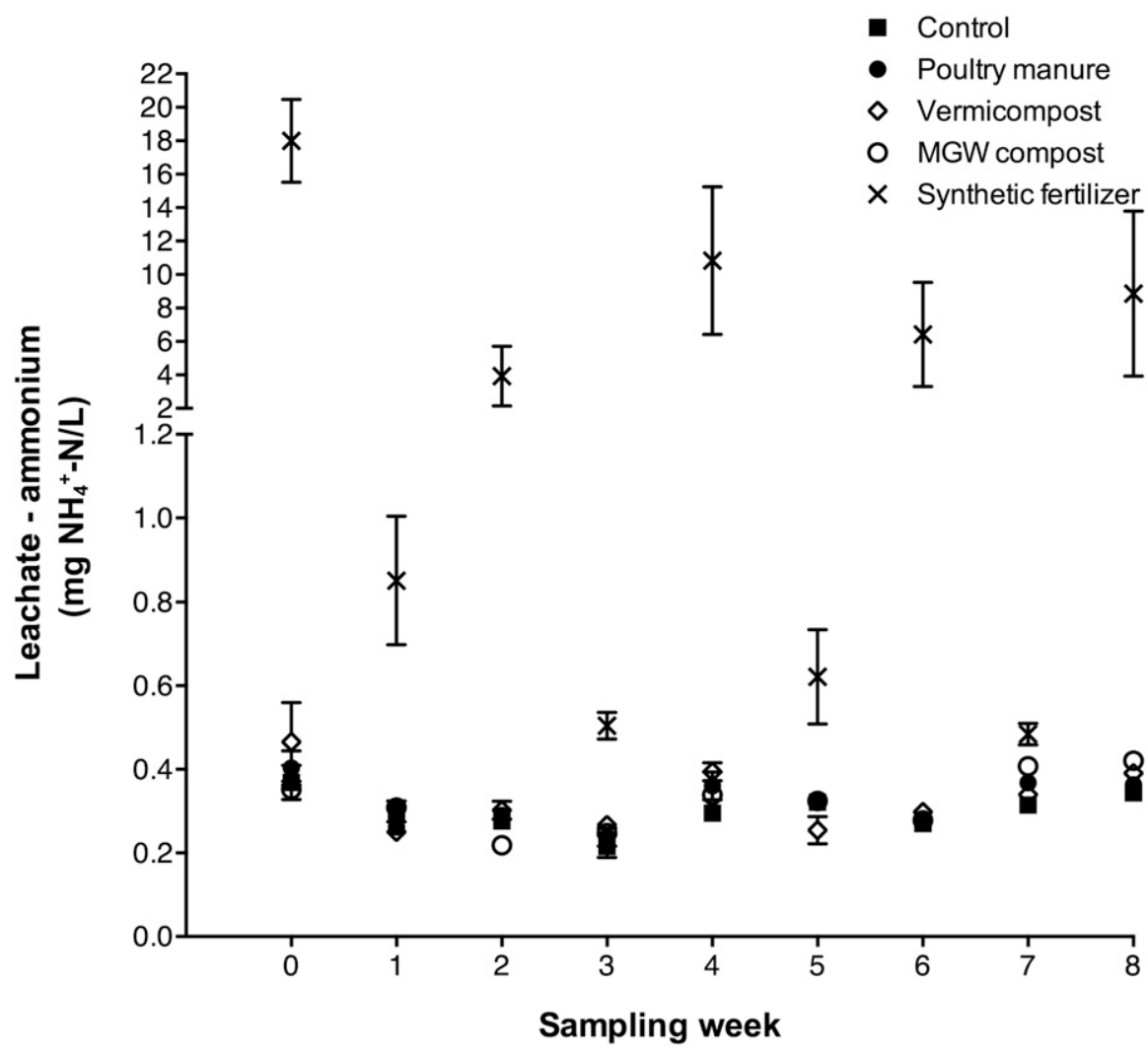

Fig. 3. Total ammonium concentration $\left(\mathrm{mg} \mathrm{NH}_{4}^{+}-\mathrm{N} / \mathrm{L}\right)$ in leachate water from rooftop farm substrate during an 8-week greenhouse experiment. Treatments include control, no added $\mathrm{N}$ input to rooftop farm substrate; poultry manure, composted poultry manure; vermicompost; municipal green waste (MGW) compost, composted municipal green waste; and synthetic fertilizer, Osmocote $^{\circledR}$ Smart-Release $14 \mathrm{~N}-4.2 \mathrm{P}-11.6 \mathrm{~K}$. Error bars represent standard error of the mean $(\mathrm{n}=5)$.

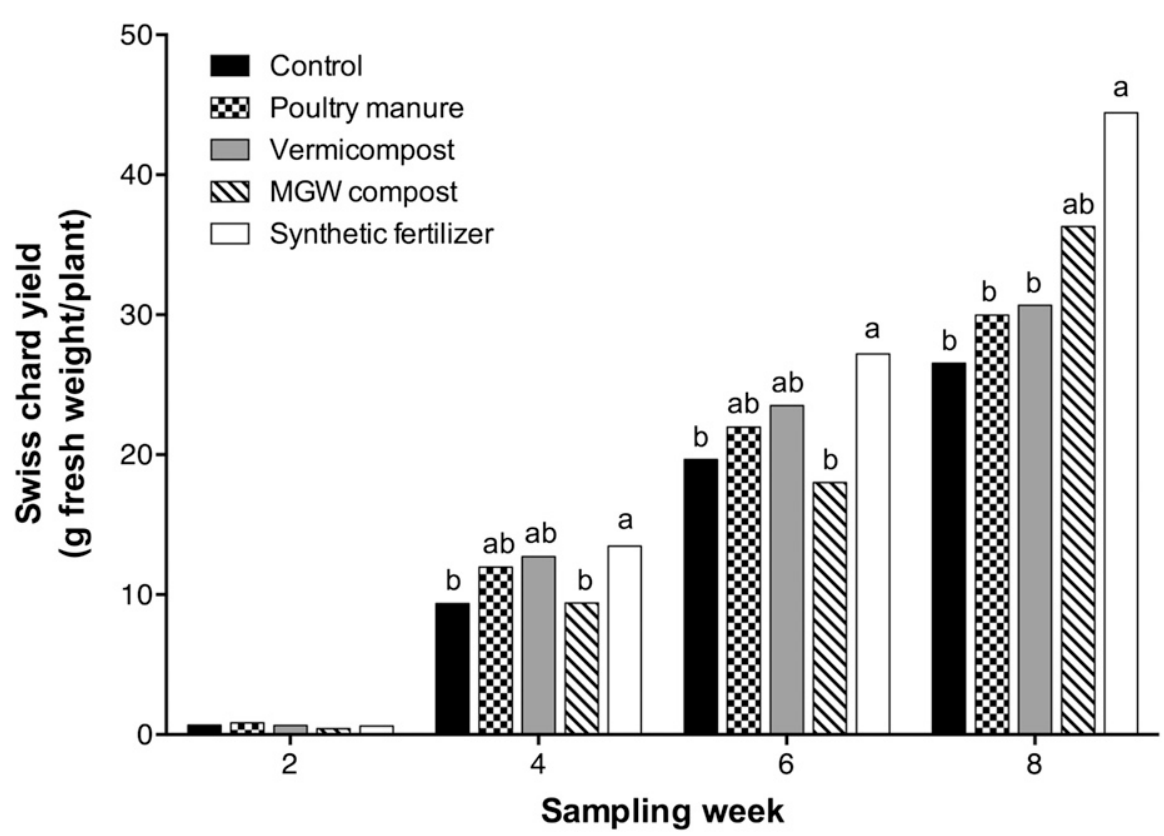

Fig. 4. Swiss chard (Beta vulgaris) aboveground biomass and yields of during an 8-week greenhouse experiment. Treatments include control, no added $\mathrm{N}$ input to rooftop farm substrate; poultry manure, composted poultry manure; vermicompost; municipal green waste (MGW) compost, composted municipal green waste; and synthetic fertilizer, Osmocote ${ }^{\circledR}$ Smart-Release 14N-4.2P-11.6K. Bars (means representing $\mathrm{n}=5$ ) within a sampling week bearing the same letter are not significantly different by Tukey's honestly significant difference test at $\alpha=0.05$. 
Table 4. Total nitrogen $(\mathrm{N})$ content, carbon-to-nitrogen ratio $(\mathrm{C}: \mathrm{N})$, and partial factor of productivity of $\mathrm{N}$ $\left(\mathrm{PFP}_{\mathrm{N}}\right)$ of swiss chard (Beta vulgaris) yields at harvest. Mean $(\mathrm{n}=5)$ separation in the same column, by Tukey's honestly significant difference test at $\alpha=0.05$ (lower case) and $\alpha=0.1$ (upper case).

\begin{tabular}{lccc}
\hline $\mathrm{N}$ input treatment & Yield N $(\mathrm{g} \mathrm{N} / \mathrm{kg})$ & $\mathrm{C}: \mathrm{N}$ & PFP $_{\mathrm{N}}(\mathrm{g}$ yield/g N applied $)$ \\
\hline Municipal green waste & $25.2 \mathrm{ab}$ & $13.6 \mathrm{AB}$ & $3.28 \mathrm{~b}$ \\
Synthetic fertilizer & $33.4 \mathrm{a}$ & $10.9 \mathrm{~B}$ & $6.37 \mathrm{a}$ \\
Composted poultry manure & $21.4 \mathrm{~b}$ & $15.2 \mathrm{~A}$ & $4.39 \mathrm{~b}$ \\
Vermicompost & $27.6 \mathrm{ab}$ & $12.2 \mathrm{AB}$ & $2.97 \mathrm{~b}$ \\
Control & $27.0 \mathrm{ab}$ & $12.4 \mathrm{AB}$ & $\mathrm{NA}$ \\
\hline
\end{tabular}

significantly within treatments across the season, suggesting that these systems are well buffered (statistical significance among weeks not shown in Table 3). With the exception of week 6 , the $\mathrm{pH}$ of the substrate of the synthetic fertilizer treatment was significantly lower than that of the control and organic $\mathrm{N}$ input treatments, which were generally not different. Although the measured $\mathrm{pH}$ values for the treatments fall within the range of $\mathrm{pH} 5.5-8.0$ that is recommended in the FLL (2002) guidelines for actively growing intensive green roofs, these values are higher than the preferred $\mathrm{pH}$ range of 6.75 for swiss chard grown in mineral soils (Jett, 2005). The lower $\mathrm{pH}$ of the substrate in the synthetic fertilizer treatment (Table 3) may have, along with other factors, contributed to higher yields in comparison with the control and organic $\mathrm{N}$ input treatments.

Substrate EC values across all treatments ranged from 2.46 to $7.66 \mathrm{dS} \cdot \mathrm{m}^{-1}$ (Table 3 ), with $\mathrm{EC}$ values gradually decreasing from the start of the experiment toward harvest. This was to be expected as salts from the substrate and $\mathrm{N}$ inputs will gradually leach out with each irrigation event that exceeds substrate moisture holding capacity and plant water uptake. The substrate from the synthetic fertilizer and MGW compost treatments showed the highest EC values across the season $\left(5.68\right.$ and $5.15 \mathrm{dS} \cdot \mathrm{m}^{-1}$, respectively). According to Warncke and Krauskopf (1983), substrate EC values exceeding 5.00 $\mathrm{dS} \cdot \mathrm{m}^{-1}$ can result in plant wilting and leaf burn. Shannon and Grieve (1998) report that swiss chard growth diminishes in sand cultures with EC exceeding $11 \mathrm{dS} \cdot \mathrm{m}^{-1}\left(\approx 3.67 \mathrm{dS} \cdot \mathrm{m}^{-1}\right.$ for saturated extract EC). While neither leaf burn nor wilting were observed in any of the treatments, rooftop farms using substrates similar to those in this study should monitor salinity to optimize crop productivity and substrate health.

Nutrient management for maximizing crop yields and reducing $N$ loss. Like most agricultural operations, rooftop farms must maximize their crop production with minimal inputs to be viable. In the case of $\mathrm{N}$ inputs, cropping systems with high nitrogen use efficiency (NUE) are key to optimizing the trade-offs among production, profit, and environmental impact. Cropping system NUE can be increased by achieving greater uptake efficiency of applied $\mathrm{N}$ inputs, by reducing the amount of $\mathrm{N}$ lost from organic and inorganic $\mathrm{N}$ pools in the growth medium, or both. Nitrogen applied via synthetic fertilizer (126 kg N/ha) and MGW compost (189 kg N/ha) were the lowest and highest, respectively, among the treatments. The partial productivity factor of $\mathrm{N}$ applied $\left(\mathrm{PFP}_{\mathrm{N}}\right)$, calculated as the ratio of the swiss chard yield ( $\mathrm{g}$ dry weight per container) to the total amount of $\mathrm{N}$ applied to the treatment ( $\mathrm{g} \mathrm{N}$ per container), was highest for the synthetic fertilizer treatment (6.37 g yield $/ \mathrm{g} \mathrm{N}$ applied) and did not differ among the organic $\mathrm{N}$ input treatments $(2.97-4.39 \mathrm{~g}$ yield/g N applied; Table 4). The substrate $\mathrm{NO}_{3}^{-}-\mathrm{N}$ levels in the synthetic fertilizer treatment, which showed the highest yields, were significantly greater than the other systems only at weeks 2,4 , and 8 (Table 3), which suggests that mineral $\mathrm{N}$ availability during these periods was critical for maximizing crop growth. The higher concentration of inorganic $\mathrm{N}$ in the leachates from the synthetic fertilizer treatment is a trade-off of the higher NUE though. This corroborates our hypothesis that the synthetic fertilizer would provide the highest $\mathrm{N}$ availability for crop growth, thereby leading to the greatest yields, but the levels of available $\mathrm{N}$ in excess of plant demand would also lead to the greatest loss of $\mathrm{N}$ in leachates, which increases the potential for negative environmental impact compared with the compost systems.

The $\mathrm{NO}_{3}^{-}-\mathrm{N}$ and $\mathrm{NH}_{4}^{+}-\mathrm{N}$ available in the substrate, as well as in the leachate of the vermicompost treatment were not different from the other organic $\mathrm{N}$ input treatments (except at week 2; Table 3), despite the lower $\mathrm{C}: \mathrm{N}$ ratio of the vermicompost treatment. Also, the yield from the vermicompost treatment was not different from the other composts. Therefore, our hypothesis that the organic $\mathrm{N}$ input treatment with the lowest $\mathrm{C}: \mathrm{N}$ ratio would release plant available $\mathrm{N}\left(\mathrm{NO}_{3}^{-}-\mathrm{N}\right.$ and $\mathrm{NH}_{4}^{+}-\mathrm{N}$ ) at a rate synchronized with crop $\mathrm{N}$ demand, and lead to the smallest $\mathrm{N}$ loss among the treatments, plus the highest yield among the compost systems was not corroborated. Moreover, our third hypothesis that $\mathrm{N}$ released from the organic $\mathrm{N}$ input treatment with the highest $\mathrm{C}: \mathrm{N}$ ratio would not meet plant $\mathrm{N}$ demand and, therefore, lead to reduced yields, was not corroborated because the MGW compost treatment (one of the highest C:N; Table 3) produced yields similar to the other organic $\mathrm{N}$ input treatments.

Of the four $\mathrm{N}$ input treatments, the treatment receiving MGW compost-N best achieved the balance between higher yields and reduced $\mathrm{N}$ losses to potential roof runoff. It is not evident from our measurements, however, that inorganic $\mathrm{N}$ availability, total substrate $\mathrm{N}$, and potential $\mathrm{N}$ mineralization concentrations contributed to the higher yields of the MGW compost treatment and the synthetic fertilizer treatments. Phosphorus and other macronutrients and micronutrients, which were not measured in this study, are also critical to crop growth (Fageria et al., 2010) and may have played a potential role in the differences observed in the yields. While the moisture holding capacities of the MGW compost, vermicompost, and composted poultry manure treatments $(12 \%, 11 \%$, and $15 \%$, respectively, including base substrate) were similar, differences in porosity (not measured) may have also been influential in creating conditions that promoted crop growth and $\mathrm{N}$ loss.

Nitrate- and ammonium-N availability in the organic $\mathrm{N}$ input treatments and the control were lower at the end of the 8-week experiment than at the beginning of the season (Table 3; significance not shown). Williams and Nelson (1992) tested several organic N sources, including sewage sludge, poultry manure sludge, bonemeal, pine needles, and poultry feathers, and found that all sources ceased releasing sufficient $\mathrm{N}$ after 6-7 weeks. To replenish the inorganic $\mathrm{N}$ pools and sustain crops grown in soilless rooftop farm substrate, applying $\mathrm{N}$ inputs throughout the growing season (which can be longer than the 8 -week period studied in this experiment) and/or supplementing organic amendments with synthetic fertilizers might improve $\mathrm{N}$ availability, thereby maximizing yields, providing $\mathrm{N}$ for subsequent crops, and promoting long-term productivity. Cover cropping with leguminous, $\mathrm{N}$-fixing crops (e.g., vetch, clover, and/or beans) have been shown to replenish $\mathrm{N}$ pools and accumulate organic matter in traditional cropping systems (Dakora and Keya, 1997; Kuo et al., 1997; Stivers and Shennan, 1991), and should be considered for fertility management on rooftop farms.

\section{Conclusions}

Despite the lower total $\mathrm{N}$ applied, the higher inorganic $\mathrm{N}\left(\mathrm{NO}_{3}^{-}\right.$and $\left.\mathrm{NH}_{4}^{+}\right)$availability in the substrate of the synthetic fertilizer treatment led to higher swiss chard yields and crop- $\mathrm{N}$ but also to higher inorganic $\mathrm{N}$ in leachate compared with the treatments receiving organic $\mathrm{N}$ inputs. Our measurements of total and inorganic substrate- $\mathrm{N}$ and $\mathrm{NH}_{4}^{+}$ and $\mathrm{NO}_{3}^{-}-\mathrm{N}$ in the leachate suggest that the MGW compost system (which had the highest $\mathrm{C}: \mathrm{N}$ ratio of the organic $\mathrm{N}$ input treatments) best achieved the balance between higher yields and reduced $\mathrm{N}$ losses via leachate. Moreover, our data show that while the form of $\mathrm{N}$ input influenced plantavailable $\mathrm{N}$ and yields, additional $\mathrm{N}$ inputs, particularly to the treatments receiving composts, will likely be necessary if a high $\mathrm{N}$-demanding crop (such as swiss chard) is to be grown in the same substrates in the long-term. It is clear that further research, particulary involving in situ experiments, is necessary to examine the complex dynamics between abiotic and biotic factors controlling mineralization and $\mathrm{N}$ availability in rooftop farm substrates receiving different amendments and fertilizers. As urban and rooftop farming become more prevalent, establishing standards, and recommendations for best management practices will be pertinent to 
optimize productivity and minimize negative environmental impacts.

\section{Literature Cited}

Berghage, R.D., D. Beattie, A.R. Jarrett, C. Thuring, F. Razaei, and T. O'connor. 2009. Green roofs for stormwater runoff control. In: National Risk Management Research Laboratory (ed.). EPA/ 600/R-09/026. Office of Research and Development, U.S. Environmental Protection Agency, Cincinnati, OH. $81 \mathrm{p}$.

Boydston, R.A., H.P. Collins, and S.F. Vaughn 2008. Response of weeds and ornamental plants to potting soil amended with dried distillers grains. HortScience 43:191-195.

Brenneisen, S. 2006. Space for urban wildlife: Designing green roofs as habitats in Switzerland. Urban Habitats 4:27-36.

Burger, M. and L.E. Jackson. 2003. Microbial immobilization of ammonium and nirate in relation to ammonification and nitrification rates in organic and conventional cropping systems. Soil Biol. Biochem. 35:29-36.

Campbell, C.A. and W. Souster. 1982. Loss of organic matter and potentially mineralizable nitrogen from Saskatchewan soils due to cropping. Can. J. Soil Sci. 62:651-656.

Carpenter, S.R., N.F. Caraco, D.L. Correll, R.W Howarth, A.N. Sharpley, and V.H. Smith. 1998. Nonpoint pollution of surface waters with phosphorus and nitrogen. Ecol. Appl. 8:559-568.

Chapin, F.S., III, P.M. Vitousek, and K.V. Cleve. 1986. The nature of nutrient limitation in plant communities. Amer. Nat. 127:48-58.

Clark, M.J. and Y. Zheng. 2013. Plant nutrition requirements for an installed sedum-vegetated green roof module system: Effects of fertilizer rate and type on plant growth and leachate nutrient content. HortScience 48:1173-1180.

Curtin, D. and C.A. Campbell. 2006. Mineralizable nitrogen. In: M.R. Carter and E.G. Gregorich (eds.). Soil sampling and methods of analysis. 2nd ed. CRC Press, Boca Raton, FL.

Czemiel Berndtsson, J. 2010. Green roof performance towards management of runoff water quantity and quality: A review. Ecol. Eng. 36:351-360

Dakora, F.D. and S.O. Keya. 1997. Contribution of legume nitrogen fixation to sustainable agriculture in Sub-Saharan Africa. Soil Biol. Biochem. 29:809-817.

Doran, J.W. 1987. Microbial biomass and mineralizable nitrogen distributions in no-tillage and plowed soils. Biol. Fert. Soils 5:68-75.

Echer, M.D.M., T. Zoz, C.D. Rossol, F. Steiner, D.D. Castagnara, and M.D.C. Lana. 2012. Plant density and nitrogen fertilization in Swiss chard. Horticultura Brasileira 30:703-707.

Emilsson, T., J. Czemiel Berndtsson, J.E. Mattsson, and K. Rolf. 2007. Effect of using conventional and controlled release fertiliser on nutrient runoff from various vegetated roof systems. Ecol. Eng. 29:260-271.

Engelbrecht, G.M., G.M. Ceronio, and P.C. Motseki. 2010. Effect of nitrogen levels and sources on production of Swiss Chard (Beta vulgaris var. Cicla). SA J. Plant Soil 27:229-234.

Fageria, N.K., V.C. Baligar, and C.A. Jones. 2010 Growth and mineral nutrition of field crops. CRC Press, Boca Raton, FL.

FLL. Forschungsgesellschaft Landschaftsentwicklung Landschaftsbau (Landscape, R., Development \& Construction Society). 2002. Guideline for the Planning, Execution, and Upkeep of Green-roof Sites.

Franzluebbers, A.J., F.M. Hons, and D.A. Zuberer. 1995. Soil organic carbon, microbial biomass, and mineralizable carbon and nitrogen in sorghum. Soil Sci. Soc. Amer. J. 59:460-466.

Gobel, P., C. Dierkes, and W.G. Coldewey. 2007. Storm water runoff concentration matrix for urban areas. J. Contam. Hydrol. 91:26-42.

Goh, K.M. and R.J. Haynes. 1986. Nitrogen and agronomic practice. In: R.J. Haynes (ed.) Mineral nitrogen in the plant-soil system. Elsevier Science, London, U.K

Groffman, P.M., N.L. Law, K.T. Belt, L.E. Band, and G.T. Fisher. 2004. Nitrogen fluxes and retention in urban watershed ecosystems. Ecosystems 7:393-403.

Hathaway, A.M., W.F. Hunt, and G.D. Jennings 2008. A field study of green roof hydrologic and water quality performance. Trans. ASABE $51: 37-44$.

Jett, J.W. 2005. Plant pH preferences [Online]. West Virginia University extension service. $30 \mathrm{Jan}$ 2015. <http://www.wvu.edu/ agexten/hortcult/ homegard/pHpref.pdf $>$.

Kuo, S., U.M. Sainju, and E.J. Jellum. 1997. Winter cover crop effects on soil organic carbon and carbohydrate in soil. Soil Sci. Soc. Amer. J 61:145-152.

Masabni, J. 2011. Swiss Chard | Commercial and Specialty Crop Guides [Online]. Texas Agri Life Extension Service: Texas A\&M. 29 Jan 2015. <Aggie-horticulture.tamu.edu/vegetable/ files/2011/10/swisschard.pdf $>$.

Materials Management \& Product Stewardship Workgroup-West Coast Climate and Materials Management Forum. 2011. Reducing Greenhouse Gas Emissions through Recycling and Composting [Online]. Seattle, WA 7 Oct. 2014. <http://www.epa.gov/region10/ pdf/climate/wccmmf/Reducing_GHGs_through Recycling_and_Composting.pdf $>$.

Michael Beman, J., K.R. Arrigo, and P.A. Matson 2005. Agricultural runoff fuels large phytoplankton blooms in vulnerable areas of the ocean. Nature 434:211-214.

Moran, A., W.F. Hunt, and J. Smith. 2005. Hydrologic and water quality performance from green roofs in Goldsboro and Raleigh, North Carolina. Proceedings of the Green Roofs for Healthy Cities Conference. Washington, DC.

Nicolardot, B., S. Recous, and B. Mary. 2001. Simulation of $\mathrm{C}$ and $\mathrm{N}$ mineralisation during crop residue decomposition: A simple dynamic model based on the $\mathrm{C}: \mathrm{N}$ ratio of the residues. Plant Soil 228:83-103.

Norberg-Hodge, H., T. Merrifield, and S. Gorelick 2002. Bringing the food economy home: Loca alternatives to global agribusiness. Zed Books, London, U.K

Norton, J.M. 1999. Nitrification. In: M.E. Sumner (ed.). Handbook of soil science. CRC Press, Boca Raton, FL.

Oberndorfer, E., J. Lundholm, B. Bass, R.R Coffman, H. Doshi, N. Dunnett, S. Gaffin, M. Köhler, K.K.Y. Liu, and B. Rowe. 2007. Green roofs as urban ecosystems: Ecological structures, functions, and services. Bioscience 57:823-833.

R 2013. R: A language and environment for statistical computing. In: R.C. Team (ed.). Foundation for Statistical Computing, Vienna, Austria.

Repository of Documents. New York State, Tribal \& Territorial Standards (US). 2000. Federal Regulations, 40 CFR 131.41, Section 1: Water Quality Regulation [Online]. In: Water Quality Standards Repository of Documents (ed.). U.S Environmental Protection Agency. Washington, DC. 24 Sept. 2013. <http://water.epa.gov/scitech swguidance/standards/wqslibrary/ny_index.cfm>.

Roe, N. 2001. Compost effects on crop growth and yield in commercial vegetable cropping systems In: P.J. Stoffella and B.A. Kahn (eds.). Compost utilization in horticultural cropping systems. CRC Press, Boca Raton, FL.

Roofmeadow. 2015. Horticultural Questions Roofmeadow - Green roofs. For good. [Online] 29 Jan. 2015. <http://www.roofmeadow.com/ contact-us/ask-charlie/horticultural-questions/>

Schomberg, H.H., S. Wietholter, T.S. Griffin, D.W Reeves, M.L. Cabrera, D.S. Fisher, D.M. Endale, J.M. Novak, K.S. Balkcom, R.L. Raper, N.R Kitchen, M.A. Locke, K.N. Potter, R.C. Schwartz, C.C. Truman, and D.D. Tyler. 2009. Assessing indices for predicting potential nitrogen mineralization in soils under different management systems. Soil Sci. Soc. Amer. J. 73:1575-1586.

Shannon, M.C. and C.M. Grieve. 1998. Tolerance of vegetable crops to salinity. Sci. Hort. 78:5-38.

Sikora, L.J. and R.A.K. Szmidt. 2001. Nitrogen sources, mineralization rates, and nitrogen nutrition benefits to plants from composts. In: P.J. Stoffella and B.A. Kahn (eds.) Compost utilization in horticultural cropping systems CRC Press, Boca Raton, FL.

Smith, W.H. 1996. Utilizing composts in land management to recycle organics. In: M. De Bertoldi, P. Sequi, B. Lemmes, and T. Papi (eds.). The science of composting. Springer, Netherlands.

Solecki, W.D., C. Rosenzweig, L. Parshall, G. Pope, M. Clark, J. Cox, and M. Wiencke. 2005. Mitigation of the heat island effect in urban New Jersey. Environ. Hazards 6:39-49.

Stanford, G. and S.J. Smith. 1972. Nitrogen mineralization potentials of soils. Proc. Soil Sci. Soc. Amer. 36:465-472.

Stivers, L.J. and C. Shennan. 1991. Meeting the nitrogen needs of processing tomatoes through winter cover cropping. J. Prod. Agr. 4:330-335.

Teemusk, A. and Ü. Mander. 2007. Rainwater runoff quantity and quality performance from a greenroof: The effects of short-term events. Ecol. Eng. 30:271-277

The Scott Company. 2009. Osmocote ${ }^{\circledR}$ Plus Multipurpose Plant [Online]. 22 Jan. 2015. <http:// www.scotts.com/smg/products/osmocote/PDF/ Osmocote $\% 20-\% 200 \% 20 \% 20 I \% 20$ Product $\% 20$ Page.pdf $>$

VanWoert, N.D., D.B. Rowe, J.A. Andresen, C.L. Rugh, R.T. Fernandez, and L. Xiao. 2005 Green roof stormwater retention: Effects of roof surface, slope, and media depth. J. Environ. Qual. 34:1036-1044.

Warncke, D. 2011. Greenhouse root media recommended chemical soil test procedures. In: The Northeast Coordinating Committee for Soi Testing (NEC-1012) (eds.). Recommended soil testing procedures for the northeastern United States. Northeastern Regional Publication No. 493, 3rd ed. Agricultural Experiment Stations of Connecticut, Delaware, Maine, Maryland, Massachusetts, New Hampshire, New Jersey, New York, Pennsylvania, Rhode Island, Vermont and West Virginia. Univ. Delaware Fact Sheets \& Pubs., Newark, DE

Warncke, D. and D.M. Krauskopf. 1983. Greenhouse growth media: Testing and nutrition guidelines. Extension Bulletin E 1736. Michigan State University Ag Facts. East Lansing, MI.

Whipker, B.E., T.J. Cavins, and W.C. Fonteno. 2001 1, 2, 3's of PourThru [Online]. North Carolina State University Floriculture Research. 16 Oct 2013. <http://www.ces.ncsu.edu/depts/hort/flor iculture/Florex/PourThru Handout 123s.pdf $>$.

Whittinghill, L.J. and D.B. Rowe. 2012. The role of green roof technology in urban agriculture. Renew. Agr. Food Syst. 27:314-322.

Williams, K.A. and P.V. Nelson. 1992. Low, controlled nutrient availability provided by organic waste materials for chrysanthemum. J. Amer. Soc. Hort. Sci. 117:422-429. 